\title{
Comparative Powder Microscopic and HPTLC Studies on Stem barks of Symplocos racemosa Roxb. and Symplocos crataegoides Ham.
}

\author{
Nartunai Govindarajan ${ }^{*}$, Uma Maheswara Reddy Cheekala ${ }^{2}$, Shantha Arcot ${ }^{3}$, Susikumar Sundaramoorthy ${ }^{4}$, Murugammal Shanmugam ${ }^{5}$, \\ Ramasamy Duraisamy ${ }^{6}$, Venkata Narasimhaji Cheemalapati ${ }^{7}$, llavarasan Raju ${ }^{8}$

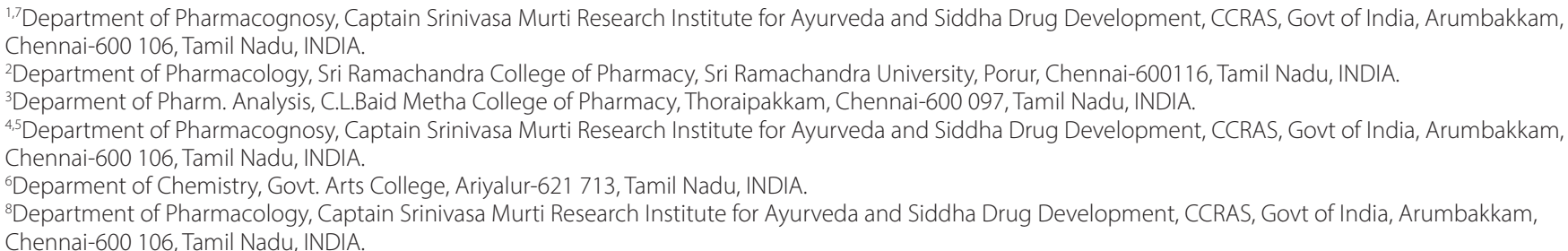

\begin{abstract}
Introduction: Comparative powder microscopic and HPTLC studies were carried out on stem barks of Symplocos racemosa Roxb. and Symplocos crataegoides Ham. to differentiate its identity in Ayurvedic formulations. Method: Powder microscopic and HPTLC studies of these barks were undertaken on a comparative basis and results are reported in this paper. The authentic samples are cleaned, powdered and passed through sieve No. 80. A few mg of powder was stained with saffranin, Toluidine blue and lodine and photographed under different magnifications with the help of NICKON Labphot -2. HPTLC studies were followed by Sethi and Wagner et al method. Results: The colour, taste, cork cells, fibres, sclereids, starch grains, calcium oxalate crystals, number of spots and Rf values of HPTLC are found to be differentiating diagnostic characters in powdered form of S. racemosa and S. crataegoides. Conclusion: The findings of the present study is believed to be helpful in standardization of Ayurvedic formulation
\end{abstract}

containing stem bark of $S$. racemosa and $S$. crataegoides as ingredients in powder form. The study sets the specific microscopic protocol and HPTLC finger print of the two drugs and may lead to global acceptance and reputation of the Ayurvedic system.

Key words: Authentication, Curna, Dasamularistam, Lodhra, Lodhrasavam, Pharmacognosy.

Corresponding author: Mr. Nartunai Govindarajan, Department of Pharmacognosy, Captain Srinivasa Murti Research Institute for Ayurveda and Siddha Drug Development, CCRAS, Govt of India, Arumbakkam, Chennai -600 106, Tamil Nadu, INDIA.

Phone no: +919894154514

Email: natrunai@yahoo.co.in

DOI : 10.5530/pj.2016.4.7

\section{INTRODUCTION}

The stem barks of the plants Symplocos racemosa Roxb. and Symplocos crataegoides Ham. (Fam. Symplocaceae) is extensively used in Indian medicine under the names of Lodhra/Patikalodhra. Mainly it is used to cure uterine complaints, vaginal and menstrual disorders. In Sanskrit the name Lodhra means that it stops ocular discharges. The important preparations using the drugs are Nyagrodhadi Kvatha curna, Nyagrodhadi curna, Lodhrasavam, Dasamularistam etc. ${ }^{1-7}$ Most of the books on Indian Materia Medica equate Symplocos racemosa as well as S. crataegoides Ham., as the botanical source of Lodhrah or Rodhrah. Two varieties of Lodhra are described in the texts viz. Sabara lodhra and Patika lodhra. Sabara lodhra is equated with Symplocos racemosa and Patika lodhra is equated with Symplocos crataegoides. ${ }^{8}$ The alcoholic extract of stem bark of Symplocos racemosa contains phenolic glycoside (benzoylsalireposide, salireposide), symplocuronic acid, sympocemoside, salirepin, $\beta$-amyrin, oleanolic acid and $\beta$-sitosterol. ${ }^{9}$ Symposide(I) a new flavan-glycoside showing anti-fibrinolytic activity, was isolated from the stem bark of S. racemosa and characterized as (-)-epiafzelechin-7- $\beta$-D-glucopyranoside. ${ }^{10}$ The following compounds isolated from the ethanolic extract of the stem bark of Symplocos crataegoides (Syn: S. paniculata) 4-(8-hydroxyethyl) cyclohexan-1-oic acid(1); androst-5(6)-ene 17-one 3 $\beta$-O- $(\beta$-D-glucopyranoside)

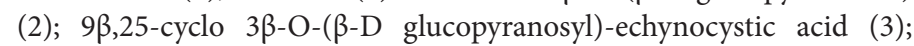
9 $\beta, 19$-cyclo 24 -methylcholan-5,22-diene 3 3 -O-( $\beta$-D-glucopyranosyl (1-6) $\alpha$-D-rhamnopyranoside) (4); 30-Et $2 \alpha, 16 \alpha$-dihydroxy $3 \beta$-O- ( $\beta$-D- glucopyranosyl) hopan-24-oic acid (5); 32,33,34-trimethyl-bacteriohopan-16-ene 3-O- $\beta$-D-glucopyranoside (6); and flavones 3,',',5',6'-tetramethoxy 7-O- $\beta$-D-glucopyranosyl (1-3) $\beta$-D-glucopyranoside (7). ${ }^{11}$

Botanically $S$. racemosa and $S$. crataegoides are different species called by similar vernacular name Lodhrah. This leads to confusion in identifying the correct botanical source of the drug. For this purpose, Powder microscopic studies and HPTLC finger printing of these barks have been undertaken on a comparative basis.

\section{MATERIALS AND METHODS \\ Collection and Identification}

The stem bark of Symplocos racemosa Roxb. was purchased locally from market and authenticated by Prof. P. jayaraman, Director, Plant Anatomy Research Centre, Chennai. The authentic stem bark of Symplocos crataegoides Ham. was supplied by Dr. G. C. Joshi, Research Officer, Regional Research Institute of Himalayan Flora, CCRAS, Thapala, Uttarakhand. The photos of the medicinal plants and its barks are given in Figure 1. The specimen vouchers of the stem barks of S. racemosa and S. crataegoides were deposited in CSMRIASDD Museum (K219/SB22 and C222/BSB26).

\section{Powder microscopic studies}

The samples were cleaned, shade dried, powdered and passed through sieve No. 80. A few mg of powder was analyzed microscopically after clearing them in Chloral hydrate solution. A few mg of powder was 
Table 1: Powder microscopic study of stem barks of S. racemosa and S. crataegoides

\begin{tabular}{|c|c|c|}
\hline Parameter & Symplocos racemosa Roxb. & Symplocos crataegoides Ham. \\
\hline $\begin{array}{l}\text { Colour, odour, } \\
\text { taste and texture }\end{array}$ & $\begin{array}{l}\text { Yellowish brown; characteristic; slightly astringent; soft } \\
\text { in texture. }\end{array}$ & $\begin{array}{l}\text { Light brown; characteristic; initially slightly sour and } \\
\text { after slightly bitter; soft in texture. }\end{array}$ \\
\hline Cork cells & $\begin{array}{l}\text { Polygonal comparatively larger in size } 70 \text { to } 110 \mu \mathrm{m} \text {, } \\
\text { slightly wavy anticlinal walls. }\end{array}$ & $\begin{array}{l}\text { Polygonal smaller in size } 50 \text { to } 70 \mu \mathrm{m} \text { straight anticlinal } \\
\text { walls filled with brownish content. }\end{array}$ \\
\hline Fibres & $\begin{array}{l}\text { Long, narrow lumen, thick walled, lignified and blunt on } \\
\text { one end, a few crystal fibres. }\end{array}$ & $\begin{array}{l}\text { Libriform fibres with tertiary thickening are common, } \\
\text { long, very narrow lumen, cylindrical, thick walled, } \\
\text { lignified and tapering on both ends. }\end{array}$ \\
\hline Sclereids & $\begin{array}{l}\text { Brachysclereids, some sclereids rectangular, lignified } \\
\text { with thick spiny outgrowth and sclerotic phellem cells or } \\
\text { phelloids, rectangular and tabular in shape with simple } \\
\text { pits in the lumen, } 320 \mu \mathrm{m} \text { long and } 130 \mu \mathrm{m} \text { wide. }\end{array}$ & $\begin{array}{l}\text { Polyhedral, more or less iso diametric sclereids } \\
\text { (Brachysclereids), thick walled, lignified } 80 \text { to } 100 \mu \mathrm{m} \\
\text { in size. }\end{array}$ \\
\hline Starch grains & $\begin{array}{l}\text { Numerous, simple as well as compound, having } 2 \text { to } 6 \\
\text { components, Y shaped hilum in centre, measuring } 4 \text { to } \\
13 \mu \mathrm{m} \text { in diameter. }\end{array}$ & Simple, round to oval, measuring 4 to $25 \mu \mathrm{m}$ in diameter. \\
\hline Crystals & Abundant Prismatic crystals of calcium oxalate. & Scarce Prismatic crystals of calcium oxalate. \\
\hline
\end{tabular}

Table 2: $\boldsymbol{R} \boldsymbol{f}$ values of chloroform and alcohol extracts

\begin{tabular}{|c|c|c|c|c|}
\hline \multirow[t]{2}{*}{$\begin{array}{l}\text { Types of lights with } \\
\text { wavelength }\end{array}$} & \multicolumn{2}{|c|}{$\begin{array}{l}\text { Chloroform extracts } \\
\text { [Mobile phase: Toluene: Ethyl acetate (8:2)] }\end{array}$} & \multicolumn{2}{|c|}{$\begin{array}{l}\text { Alcohol extracts } \\
\text { [Mobile Phase: Toluene: Ethyl acetate: Formic } \\
\text { acid }(7: 3: 0.1) \text { ] }\end{array}$} \\
\hline & S. racemosa & S. crataegoides & S. racemosa & S. crataegoides \\
\hline \multirow{3}{*}{ UV-254 nm } & 0.77 Green & 0.92 Green & 0.32 Green & 0.89 Green \\
\hline & 0.63 Green & 0.17 Green & & 0.32 Green \\
\hline & 0.17 Green & & & \\
\hline \multirow{7}{*}{ UV-366 nm } & 0.62 Blue & $0.79 \mathrm{Red}$ & 0.92 Fluorescent Blue & 0.92 Fluorescent Blue \\
\hline & 0.40 Blue & 0.64 Fluorescent blue & 0.83 Blue & 0.83 Blue \\
\hline & 0.20 Blue & $0.43 \mathrm{Red}$ & 0.77 Blue & 0.77 Fluorescent Blue \\
\hline & 0.15 Fluorescent blue & 0.37 Blue & 0.31 Blue & 0.31 Blue \\
\hline & 0.11 Fluorescent blue & 0.25 Blue & & \\
\hline & & 0.20 Blue & & \\
\hline & & 0.11 Blue & & \\
\hline \multirow{6}{*}{$\begin{array}{l}\text { Visible Light } \\
\text { (after derivatisation } \\
\text { vanillin-sulphuric acid } \\
\text { reagent) }\end{array}$} & 0.63 Grey & 0.78 Grey & & 0.90 Grey \\
\hline & 0.46 Grey & 0.65 Violet & & \\
\hline & 0.37 Grey & 0.50 Grey & & \\
\hline & & 0.45 Grey & & \\
\hline & & 0.37 Violet & & \\
\hline & & 0.13 Grey & & \\
\hline
\end{tabular}

stained with saffranin, Toluidine blue and Iodine as per the procedures ${ }^{12}$ and photographed under different magnifications with the help of NICKON Labphot -2 microscopic unit.

\section{Preparation of extracts for TLC/HPTLC studies}

$5 \mathrm{~g}$ of drug of each sample were shade dried and coarsely powdered and defatted with hexane. The plant materials were packed in a Soxhlet apparatus and extracted successively with chloroform and ethanol for 5 hrs separately. The extracts were filtered by using Whatmann No.1 filter paper. The extracts were concentrated on water bath and made up to $10 \mathrm{ml}$ volumetric flask.

\section{Method for developing TLC/HPTLC}

Instrument: CAMAG (Switzerland), sample applicator: Camag Linomat-IV applicator with $\mathrm{N}_{2}$ gas flow, photo documentation system: Digi store-2 documentation system with win cats and video scan software, scanner: Camag HPTLC scanner-3 (030618), win cats-IV, development chamber: Camag HPTLC $10 \times 10,10 \times 20$ twin trough linear development chamber, quantity applied: $10 \mu \mathrm{l}$ for extracts and $4 \mu \mathrm{l}$ for standards, stationary phase: Aluminium plate precoated with silica gel $60 \mathrm{~F}_{254}$ (E. Merck), plate thickness: $0.2 \mathrm{~mm}$, scanning wavelength: $254 \mathrm{~nm}$, laboratory condition: $20 \pm 5^{\circ} \mathrm{C}$ and $53 \%$ relative humidity. The chloroform and alcohol extract 


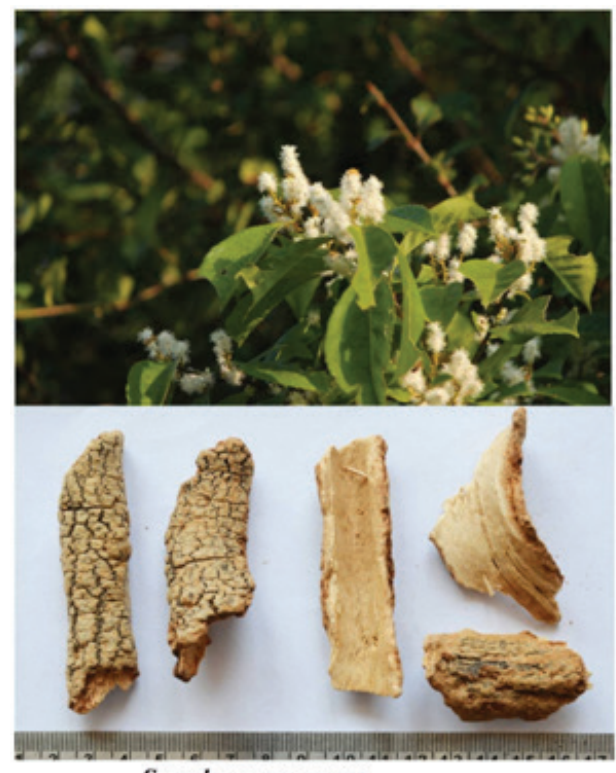

Symplocos racemosa

Figure 1: S. racemosa and S. crataegoides-Twig with flowers and stem barks.

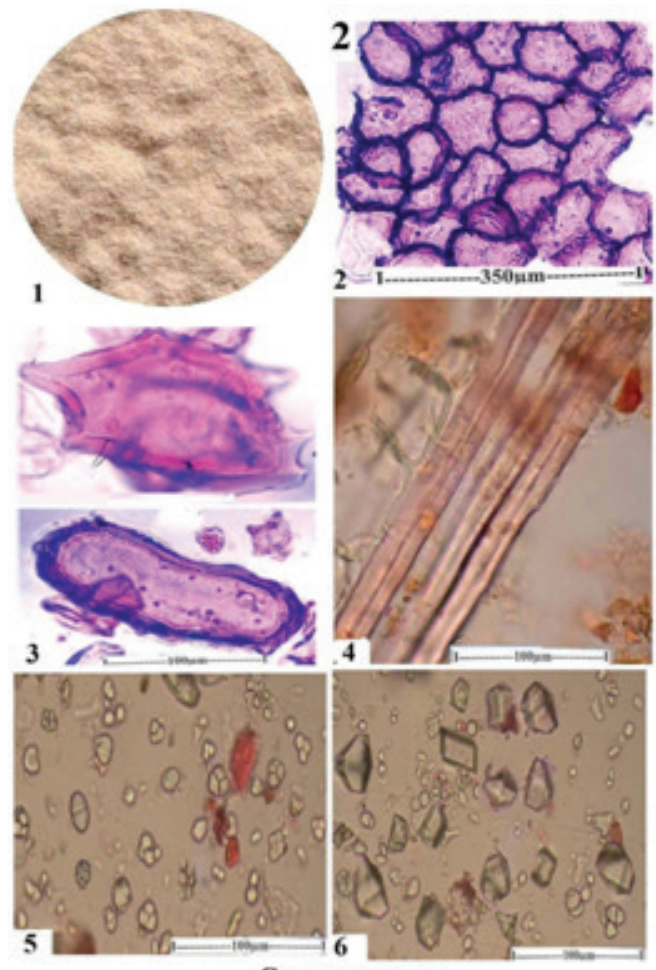

S. racemosa
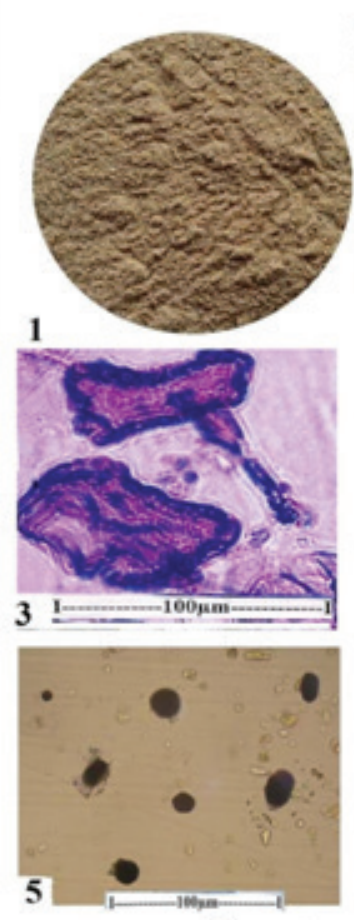

S. crataegoides
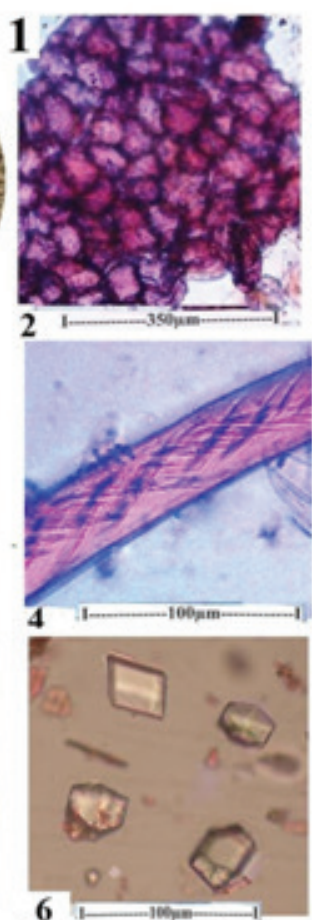

Figure 3: Symplocos crataegoides

Symplocos crataegoides

1. Powder

2. Cork cells in surface view

3. Sclereids

4. Libriform fibre (Tertiary thickening)

5. Starch grains (simple)

6. Prismatic crystals of calcium oxalate (scarce). 

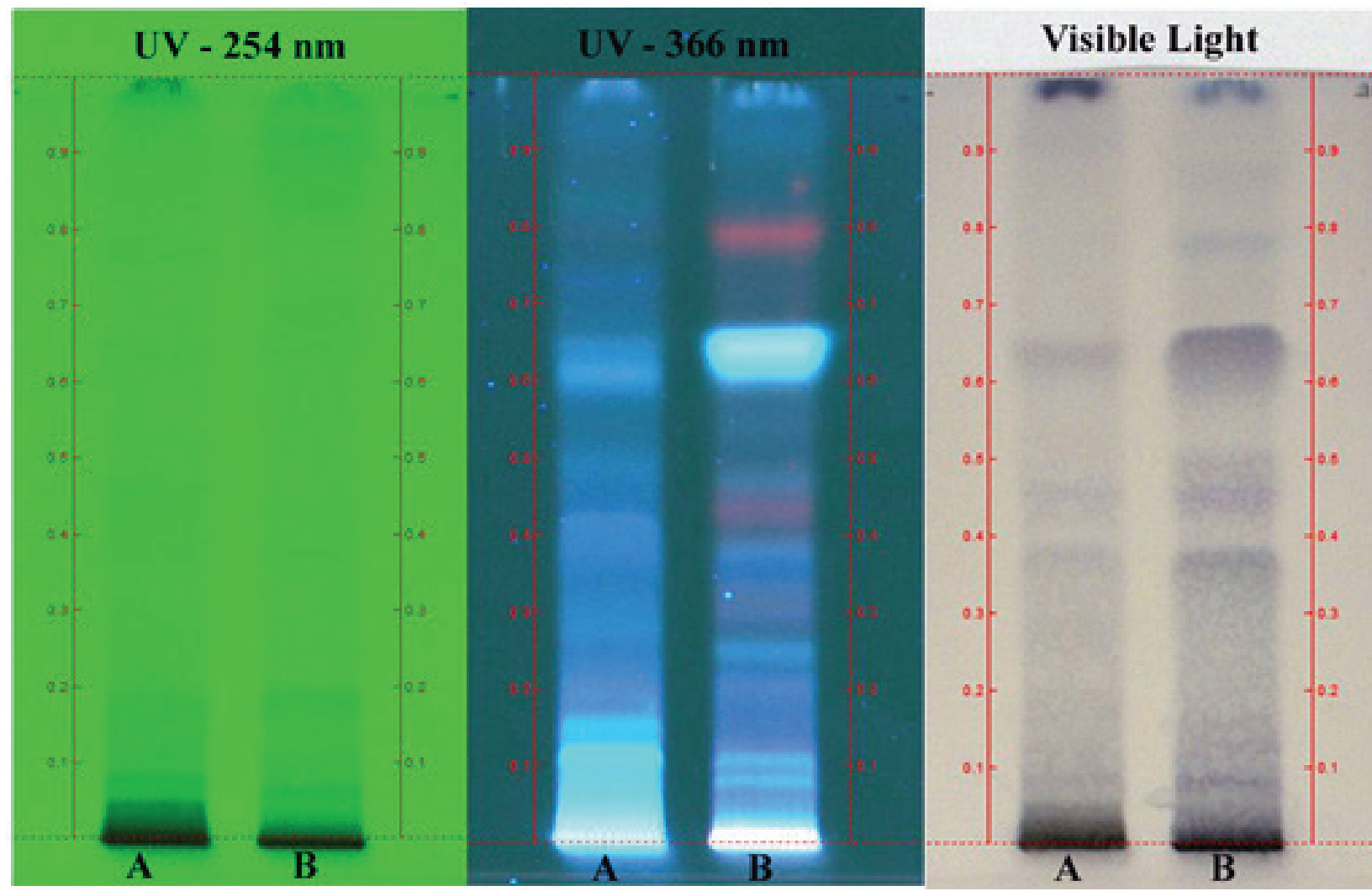

Figure 4: TLC profile of chloroform extracts of S. racemosa (A) and S. crataegoides (B).

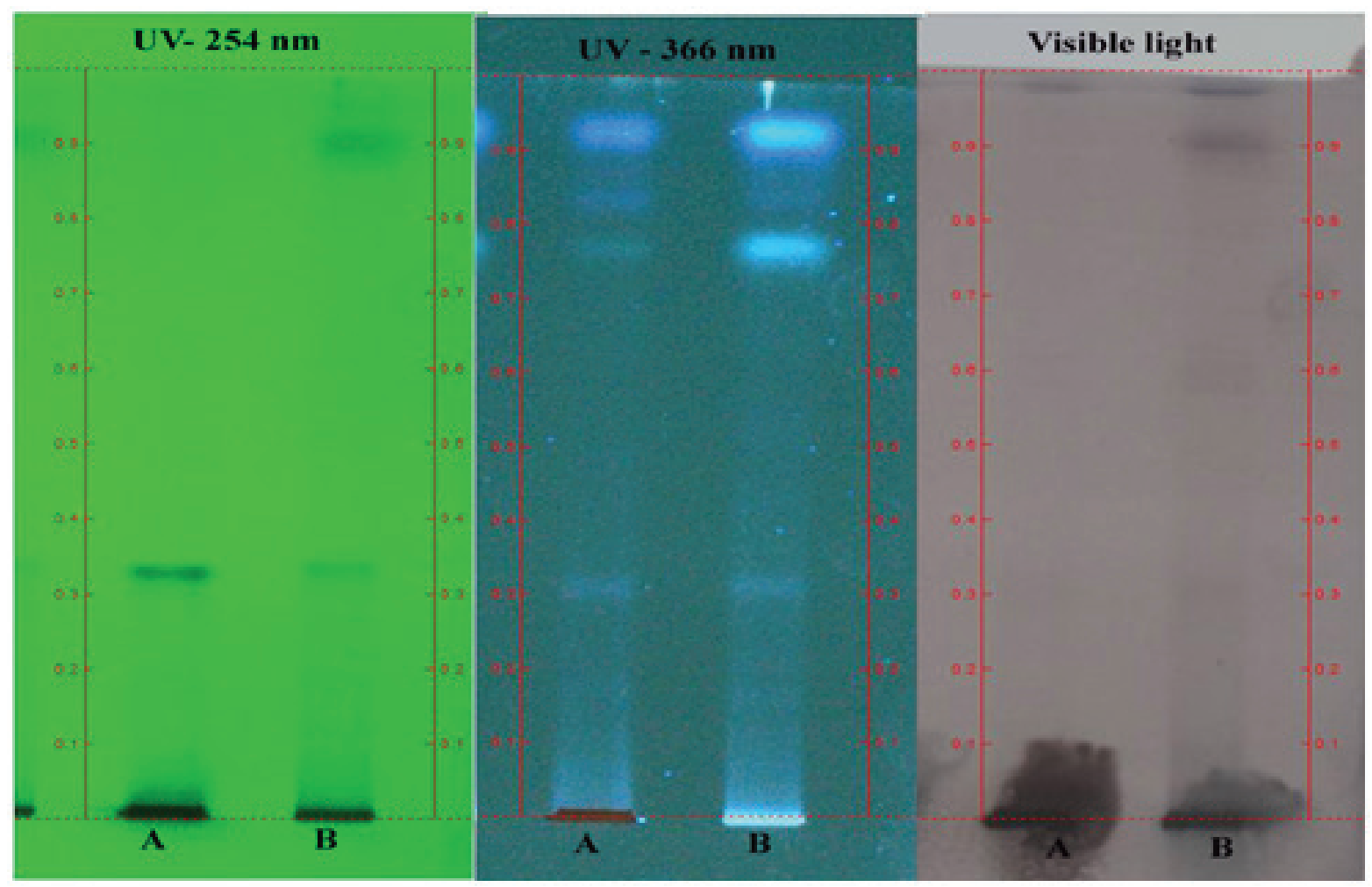

Figure 5: TLC profile of alcohol extracts of S. racemosa (A) and S. crataegoides (B). 

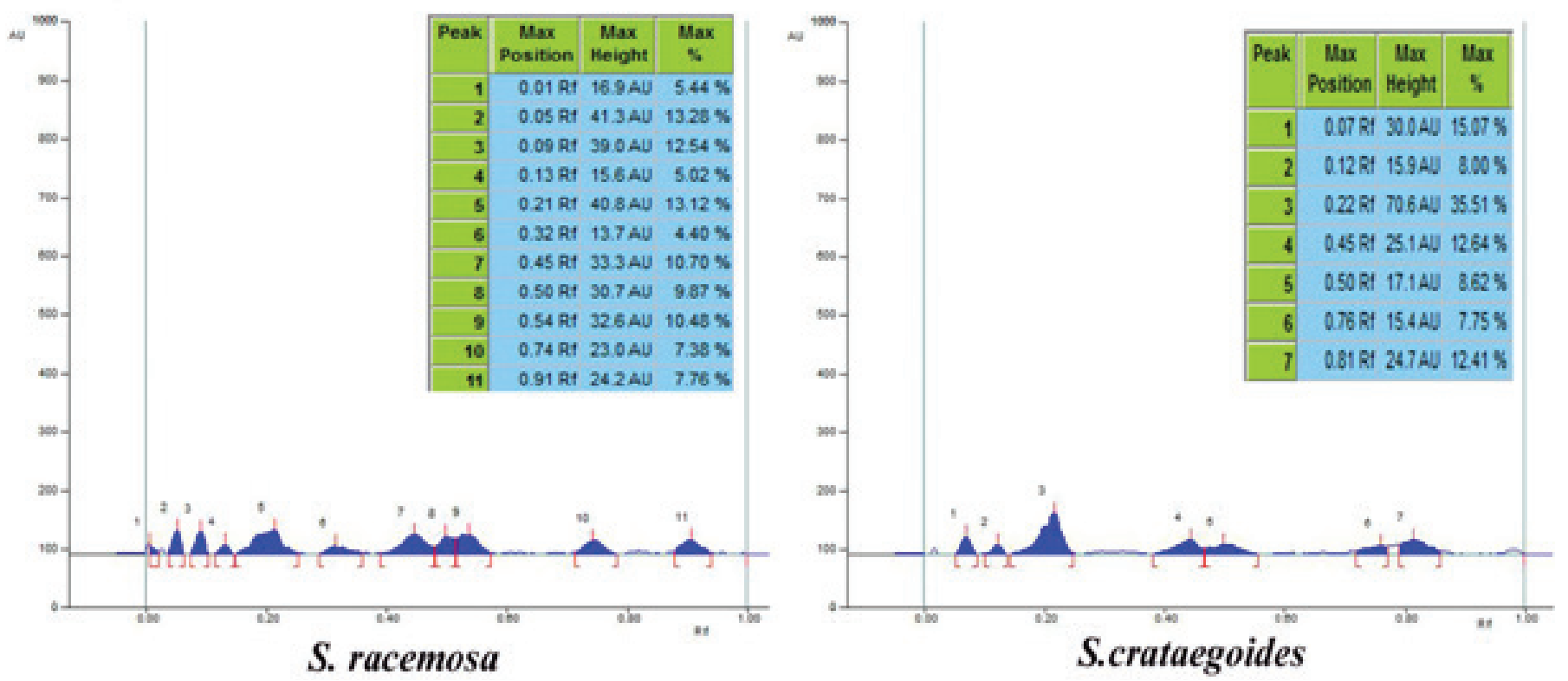

Figure 6: HPTLC profile of chloroform extracts of S. racemosa and S. crataegoides.

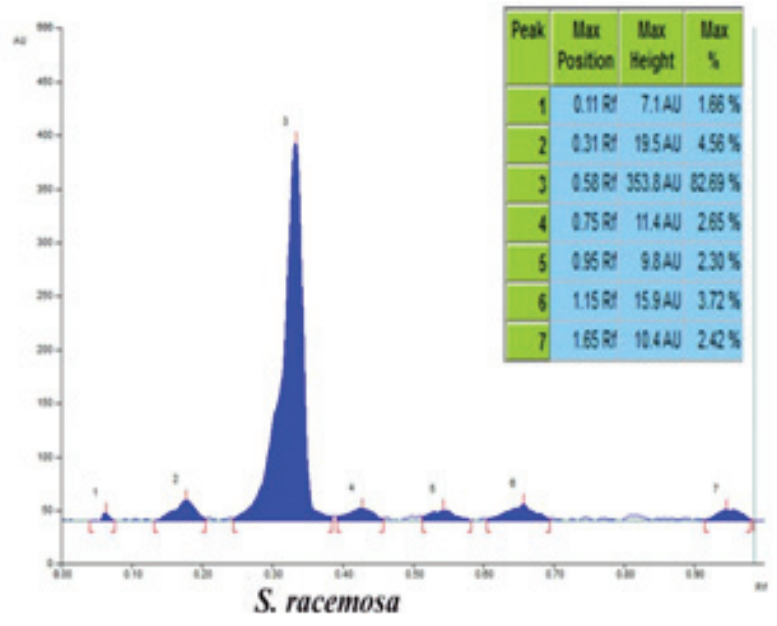

Figure 7: HPTLC profile of alcohol extracts of S. racemosa and S. crataegoides.

of both stem barks were chromatographed using toluene: ethyl acetate (8: 2), toluene: ethyl acetate: formic acid $(7: 3: 0.1)$ respectively.

The plate was developed upto a height of $8 \mathrm{~cm}$, air dried, spots were observed under the UV light at $254 \mathrm{~nm}$ and $366 \mathrm{~nm}$. The HPTLC finger print profiles were also recorded at $254 \mathrm{~nm}$. Finally the plates were derivatized using vanillin sulphuric acid reagent heated at $105^{\circ} \mathrm{C}$ till colour spots appeared. ${ }^{13,14}$

\section{RESULTS}

Powdered stem bark of Symplocos racemosa and Symplocos crataegoides were studied for microscopic point of view and given in Table 1 and Figure 2 and 3.

Different compositions of the mobile phase for TLC and HPTLC analysis were tested in order to obtain high resolution and reproducible peaks. The TLC profile of chloroform and alcohol extract of S. racemosa and $S$. crataegoides is shown in Figure 4 and 5. The corresponding $R f$ values of various spots for chloroform and alcohol extract is given in Table 2.

HPTLC finger print profile of chloroform extract of $S$. racemosa and S. crataegoides showed 11 and 7 peaks respectively (Figure 6).

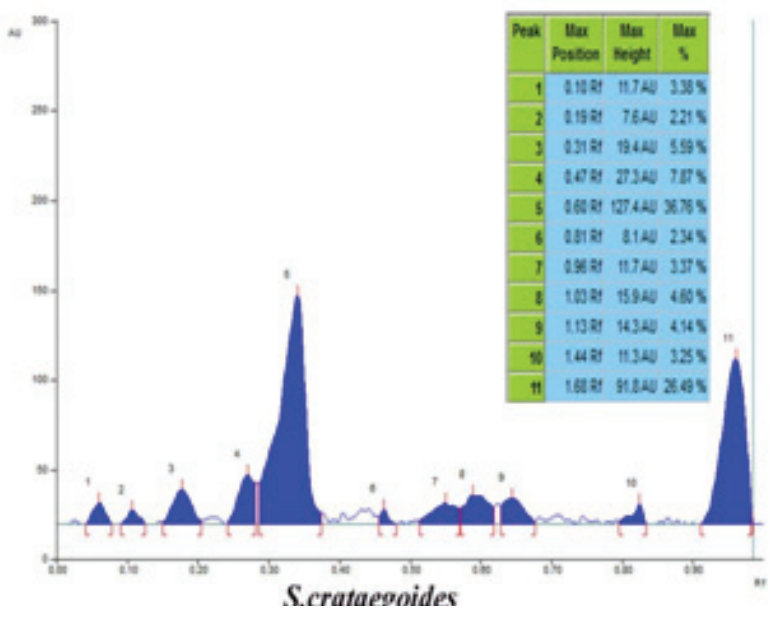

HPTLC finger print profile of alcohol extract of S. racemosa and S. crataegoides showed 7 and 11 peaks respectively (Figure 7).

\section{DISCUSSION}

Microscopic method of authentication is the first and fundamental step for standardization of herbal formulation. The findings of the present study is believed to be helpful in standardization of Ayurvedic formulation containing stem bark of $S$. racemosa and S. crataegoides as ingredients in powder form. HPTLC profile of chloroform and alcoholic extract provides a suitable method for monitoring the identity, purity and also standardization of the drug. The study sets the specific microscopic protocols of the two drugs and may lead to global acceptance and reputation of the Ayurvedic system.

\section{CONCLUSION}

The present study, analysed the powder microscopic characters of stem barks of Symplocos racemosa Roxb and Symplocos crataegoides Ham. and HPTLC fingerprint of chloroform and alcoholic extract of the same respectively. The results will be helpful in differentiating these barks in 
powdered form or in authentication/identification of the crude drug/raw drug and in standardization of Ayurvedic formulation Curna.

\section{ACKNOWLEDGEMENT}

The authors are very grateful to the Director General, Central Council for Research in Ayurvedic Sciences, New Delhi, for his encouragement and providing opportunity to conduct this study.

\section{CONFLICT OF INTEREST}

The author declare no conflict of interest.

\section{ABBREVIATION USED}

HPTLC: High Performance Thin Layer Chromatography; Rf: Retention factor; TLC: Thin Layer Chromatography; UV: Ultra violet.

\section{REFERENCES}

1. Anonymous. The Ayurvedic Formulary of India, Part-I, $2^{\text {nd }}$ revised English Ed. Govt. of India, Ministry of Health and Family Welfare, Dept. of Indian systems of Medicine and Homoeopathy: New Delhi; 2003.

2. Narayana AK, Namboodiri AN, Kolammal M. Pharmacognosy of Ayurvedic Drugs (Kerala). The Central Research Institute, University of Travancore. 1957;1(3):65-74.
3. Jain SK. Medicinal Plants, India-The Land and the People. National Book Trust, India. 1968;166-7.

4. Joshi SG. Medicinal Plants, Oxford and IBH Publishing Co. Pvt. Ltd., New Delhi: 2000;389.

5. Kirtikar KR, Basu BD. Indian Medicinal Plants, Vol. II, $2^{\text {nd }}$ Ed. 1935 (Rep. 1975); 1510-3.

6. Nadkarni AK. Dr.K.M.Nadkarni's Indian Meteria Medica, Vol.I, Popular Prakashan, $1954 ; 1186-8$.

7. Kurup PNV, Ramadas VNK, Prajapati Joshi. Handbook of Medicinal Plants, Vol.1, 1977;135-6.

8. Sivarajan WV, Indira Balachandran. Ayurvedic Drugs and their Plant Sources, Published by Mohan primlani for Oxford and IBH Publishing Co. Pvt.Ltd.: 1994;279.

9. Dhirender K, Disha S, Pawan K, JyotiY, Ruby T. Symplocos racemosa: its chemistry, medicinal uses and pharmacological activities, Pharmacologyonline, (3, News letter), Database: CAPLUS; 2010;904-17.

10. Dhaon R, Jain GK, Sarin JPS, Khanna NM. A new anti-fibrinolytic glycoside from Symplocos racemosa Roxb. Indian Journal of Chemistry. Section B. 1989; 28B(11): 982-3.

11. Badoni SR, Kumar SD, Ravindra S, Randhir S, Maniyari RMS. Chemical constituents from the stem bark of Symplocos paniculata Thunb. with antimicrobial, analgesic and anti-inflammatory activities. Journal of Ethnopharmacology. 2011; 135(1):78-87.

12. O'Brien TP, Feder N, Mc Cull ME. Polychromatic staining of Plant cell walls by Toluidine blue-O.Protoplasma. 1964;59:364-73.

13. Sethi PD. High Performance Thin Layer Chromatography, $1^{\text {st }}$ Ed. Vol. X, CBS Publishers and Distributors; New Delhi: 1996.

14. Wagner H, Bladt S. Plant Drug Analysis A Thin Layer Chromatography Atlas, $2^{\text {nd }}$ Ed. Springer-Verlag; Germany: 1996.

\section{PICTORIAL ABSTRACT}
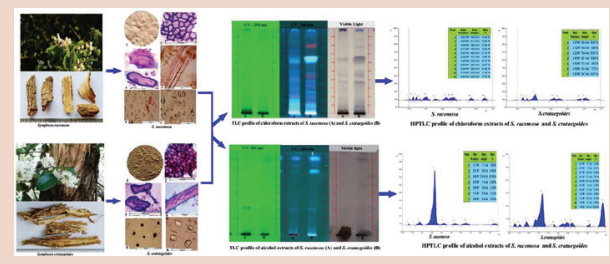

\section{SUMMARY}

- Botanically Symplocos crataegoides and Symplocos racemosa are different species called by similar vernacular name Lodhrah.

- Comparative powder microscopic and HPTLC studies were undertaken to differentiate its identity.

- Findings of the study helpful in standardization of Ayurvedic formulation containing these plant drugs.

- This study sets the specific microscopic and HPTLC protocols of the two drugs and may lead to global acceptance and reputation of the Ayurvedic system.

\section{ABOUT AUTHORS}

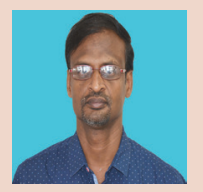

Nartunai Govindarajan: Is a Research Officer (Pharmacognosy) at Captain Srinivasa Murti Research Institute for Ayurveda and Siddha Drug Development, Chennai, Under CCRAS, Ministry of AYUSH, Govt. of India. His doctoral research focused on developing quality standards for medicinal plants used in Ayurveda. He has projects in Intra Mural and Extra Mural Research Schemes. Has experience in the area of Pharmacognosy. Developed monographs for Ayurvedic Pharmacopoeia of India and Quality Standards for Indian Medicinal Plants by ICMR.

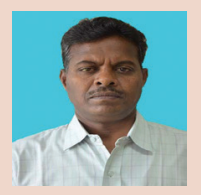

llavarasan Raju: Is an Assistant Director (S-III) in-charge at Captain Srinivasa Murti Research Institute for Ayurveda and Siddha Drug Development, Chennai, Under CCRAS, Ministry of AYUSH, Govt. of India. He has projects in Intra Mural and Extra Mural Research Schemes. Has vast experience in the area of Pharmacology and Herba Drug Standardization. Guiding students for Ph.D., studies of various universities. 